\title{
Retention Factors for Trace Metal Elements in Solid Phase and Applicable Adsorption Models: Case of Moringa oleifera
}

\author{
Mariette Désirée Yehe1,2*, Edwige Odoh³ ${ }^{1,}$ Patrick Grah Atheba4, Joel Cyriaque Dadje1, \\ Gildas Komenan Gbassi1,2
}

${ }^{1}$ Département des Sciences Analytiques et Santé Publique, UFR Sciences Pharmaceutiques et Biologiques, Université Félix Houphouët Boigny, Abidjan, Côte d'Ivoire

${ }^{2}$ Laboratoire National de la Santé Publique (LNSP), Service Contrôle des Aliments, Abidjan, Côte d'Ivoire

${ }^{3}$ Département des Sciences du Médicament, UFR Sciences Pharmaceutiques et Biologiques, Université Félix Houphouët Boigny, Abidjan, Côte d'Ivoire

${ }^{4}$ Laboratoire de Constitution et Réaction de la Matière, UFR Sciences des Structures de la Matière et Technologie, Université Félix Houphouët Boigny, Abidjan, Côte d'Ivoire

Email: *desireeyehe@gmail.com

How to cite this paper: Yehe, M.D., Odoh, E., Atheba, P.G., Dadje, J.C. and Gbassi, G.K. (2021) Retention Factors for Trace Metal Elements in Solid Phase and Applicable Adsorption Models: Case of Moringa oleifera. Open Journal of Physical Chemistry, 11, 182-195.

https://doi.org/10.4236/ojpc.2021.113011

Received: June 18, 2021

Accepted: August 23, 2021

Published: August 26, 2021

Copyright (C) 2021 by author(s) and Scientific Research Publishing Inc. This work is licensed under the Creative Commons Attribution International License (CC BY 4.0).

http://creativecommons.org/licenses/by/4.0/

\begin{abstract}
Moringa oleifera is an edible plant cultivated throughout the tropical belt. It belongs to the family Moringaceae and is one of its 14 known species. This paper presents a synthesis of the main factors responsible for the retention of trace metal elements (TMEs) by Moringa oleifera seed powder, a natural adsorbent. The five main factors studied are metal concentration, solution $\mathrm{pH}$, adsorbent particle size, adsorbent dose and adsorbent/adsorbate contact time. Through these factors, we present the optimal conditions for removal of these TMEs, as well as adsorption isotherm models appropriate for the conditions of retention of these metal cations by the adsorbent. The times of $20 \mathrm{~min}$ (GD) and $50 \mathrm{~min}$ (GND) are the equilibrium times obtained in our study. An optimal adsorbent mass (GD and GND powders) of $4.5 \mathrm{~g}$ was found. $20 \%$ to $97 \%$ abatement is observed for average $\mathrm{pH}$ values between 6 and 8 . The coefficients of determination $\left(\mathrm{R}^{2}\right)$ obtained $(0.972,0.963,0.991$ and 0.799$)$ during the isotherm experiments carried out at $20^{\circ} \mathrm{C}, 30^{\circ} \mathrm{C}, 40^{\circ} \mathrm{C}$ and $50^{\circ} \mathrm{C}$ are close to 1 . Also, the separation factor $\left(\mathrm{R}_{\mathrm{L}}\right)$, an essential characteristic of the Langmuir isotherm whose values are between 0 and 1, attest to the applicability of the Langmuir isotherm model to fit the experimental data of copper adsorption by Moringa powders. In this paper, we are particularly interested in the following TMEs ( $\mathrm{Mn}, \mathrm{Ni}, \mathrm{Cr}, \mathrm{Cu}, \mathrm{Cd}, \mathrm{Co}, \mathrm{Pb}, \mathrm{Fe}, \mathrm{Zn}, \mathrm{Ag}$ ).
\end{abstract}

\section{Keywords}

Moringa oleifera, Adsorption, Trace Metal Elements (TMEs) 


\section{Introduction}

The term "trace metal elements" (TMEs) is tending to replace the term "heavy metals", which has no real scientific or legal definition that is unanimously recognized [1]. TMEs are naturally present in soils, some of which are essential for plants. They are found in run-off water from roads and commercial areas, metal foundries, plastic effluents, textiles, microelectronics, wood industries, agriculture (fertiliser and pesticide use) but are largely derived from industrial waste [2] [3].

TMEs can be removed from aqueous solutions by conventional methods (precipitation, redox, ion exchange, mechanical filtration, electrochemistry, reverse osmosis) [4]. However, the inefficiency and extremely high cost of these methods limit their use, and the environmental side effects have led to a growing interest in plant-derived adsorbents, such as Moringa oleifera (MO) [5]. The latter has several advantages over synthetic adsorbents.

In Ivory Coast, the most used natural adsorbents are made from coconut shellactivated carbon [6]. Faced with this observation, we wanted to valorize other (local natural adsorbents, other than activated carbons. Thus, we were particularly interested in powders from hulled and unhulled seeds of Moringa oleifera, a tree that has the advantage of being locally known and used. Indeed, a comparative study conducted in Abidjan by Tanauh [7] showed that Moringa occupied a knowledge level of $78.2 \%$ by the study population in Abidjan. It is known as a miracle tree, good for health and possessing several virtues. Also, the literature mentions studies using separately as natural adsorbent the powder from dehulled Moringa oleifera seeds [8] on the one hand and the hulls of Moringa oleifera seeds [9] on the other hand, but there are no previous studies using unhulled Moringa oleifera seed powder as a natural adsorbent for metal adsorption.

\section{Retention Factors for TMEs}

A number of works mention the use of MO to remove TMEs from aqueous solutions. This work reviews different parameters studied during the removal of TMEs by $\mathrm{MO}$, as well as the adsorption isotherm models applicable to this adsorbent. The TMEs studied in this work are found in water in cationic form, i.e. $\mathrm{Mn}^{2+}$, $\mathrm{Ni}^{2+}, \mathrm{Cr}^{3+}, \mathrm{Cu}^{2+}, \mathrm{Co}^{2+}, \mathrm{Fe}^{2+}, \mathrm{Zn}^{2+}, \mathrm{Cd}^{2+}, \mathrm{Ag}^{2+}, \mathrm{Pb}^{2+}$.

The preparation method of Moringa seed powders and the physicochemical, structural and morphological parameters have been previously described in our article published in June 2019 [10].

\subsection{Effect of Metal Concentration}

Farrokhzadeh et al. [11] worked on the removal of TMEs $\left(\mathrm{Mn}^{2+}, \mathrm{Ni}^{2+}, \mathrm{Cr}^{3+}, \mathrm{Cu}^{2+}\right.$, $\mathrm{Fe}^{2+}$, and $\mathrm{Zn}^{2+}$ ) by deshelled MO seed powders in aqueous solution. They reported an initial metal concentration of 50, 100 and $200 \mathrm{mg} \cdot \mathrm{L}^{-1}$, with an adsorption percentage of $35 \%$ at the minimum concentration of $50 \mathrm{mg} \cdot \mathrm{L}^{-1}$. An increase in the initial concentration decreased the adsorption percentage.

Bhatti et al. [3] in their study on $\mathrm{Zn}^{2+}$ removal by $\mathrm{MO}$ pod biomass also re- 
ported an initial metal concentration of 50, 100 and $200 \mathrm{mg} \cdot \mathrm{L}^{-1}$, with an adsorption percentage of $74.76 \%$ at the minimum concentration of $50 \mathrm{mg} \cdot \mathrm{L}^{-1}$. An increase in the initial concentration also decreased the adsorption percentage.

Sharma et al. [7], in their study on the removal of cadmium $\left(\mathrm{Cd}^{2+}\right)$ by dehulled MO seed powders, observed that for an initial metal concentration ranging from $10-100 \mathrm{mg} \cdot \mathrm{L}^{-1}$, the adsorption percentage increased reaching a constant level of $85 \%$ at $25 \mathrm{mg} \cdot \mathrm{L}^{-1}$.

Kalavathy and Miranda [2] studied the adsorption of $\mathrm{Cu}^{2+}, \mathrm{Ni}^{2+}$ and $\mathrm{Zn}^{2+}$ in the aqueous phase by activated carbon from $\mathrm{MO}$ wood. They reported initial concentrations ranging from $10-50 \mathrm{mg} \cdot \mathrm{L}^{-1}$. The amount of metal adsorbed per unit weight increased with the initial metal concentration. The maximum adsorption capacity is $10.08 \mathrm{mg} \cdot \mathrm{g}^{-1} ; 17.48 \mathrm{mg} \cdot \mathrm{g}^{-1}$ and $14.16 \mathrm{mg} \cdot \mathrm{g}^{-1}$ for $\mathrm{Cu}^{2+}, \mathrm{Ni}^{2+}$ and $\mathrm{Zn}^{2+}$ respectively.

The authors asserted that the lower the initial metal concentration, the greater the removal of this metal. This observation may be due to the saturation of the binding site of the adsorbent with the metal or to the fact that the rate of adsorption is a function of the initial adsorbate concentration.

\subsection{Effect of Solution $\mathrm{pH}$}

Farrokhzadeh et al. [11] reported three $\mathrm{pH}$ values: $\mathrm{pH} 3, \mathrm{pH} 5$ and $\mathrm{pH} 7$ in their study on the removal of metals $\left(\mathrm{Mn}^{2+}, \mathrm{Ni}^{2+}, \mathrm{Cr}^{3+}, \mathrm{Cu}^{2+}, \mathrm{Fe}^{2+}\right.$ and $\left.\mathrm{Zn}^{2+}\right)$ by $\mathrm{MO}$ seed powders in aqueous solution. They asserted that the adsorption percentage was higher (30\%) at $\mathrm{pH} 7$. The removal of $\mathrm{Fe}^{2+}$ and $\mathrm{Cu}^{2+}$ increased with increasing $\mathrm{pH}$ of the solutions, which was in compliance with previous studies [11] [12]. However, the minimum removal efficiency of $\mathrm{Ni}^{2+}, \mathrm{Cr}^{3+}$ and $\mathrm{Zn}^{2+}(25 \%)$ was obtained at $\mathrm{pH} 5$. On the other hand, $\mathrm{Mn}^{2+}$ had the highest removal efficiency at $\mathrm{pH}$ 5. Bhatti et al. [3] also showed that the adsorption of $\mathrm{Zn}^{2+}$ increased with increasing $\mathrm{pH}$.

Sharma et al. [8], in their study on $\mathrm{Cd}^{2+}$ removal by MO seed powder, observed that the percentage adsorption of $\mathrm{Cd}^{2+}$ by plant biomass increased as the $\mathrm{pH}$ of the solution increased from 4.5 to 8.5. The adsorption profile of $\mathrm{Cd}^{2+}$ by MO powder shows that the adsorption is $\mathrm{pH}$ dependent, with a maximum adsorption of $84 \%$ at $\mathrm{pH}$ 6.5. Ajmal et al. [9] showed an increase in $\mathrm{Cd}^{2+}$ adsorption up to $\mathrm{pH} 8.5$.

Araujo et al. [13] worked on the characterization and use of $\mathrm{MO}$ seeds as a biosorbent to remove ions $\left(\mathrm{Cd}^{2+}, \mathrm{Pb}^{2+}, \mathrm{Co}^{2+}, \mathrm{Cu}^{2+}, \mathrm{Ag}^{+}\right)$from aqueous effluents. They reported an optimum $\mathrm{pH}$ value of 6.5 for a $\mathrm{pH}$ range initially between 2 and 8. Furthermore, Alves et al. [14] noted that above $\mathrm{pH}$ 6.5, the surface of the adsorbent is negatively charged and adsorbs positively charged species. The percentage removal of metal ions can be explained, according to Araujo et al. by the difference in the size of the ionic radius of the chemical species. Among TMEs studied, $\mathrm{Pb}^{2+}$ had a larger ionic radius and therefore a higher adsorption capacity, while $\mathrm{Co}^{2+}$ had a lower adsorption capacity [15]. 
Bhatti et al. [3] worked over a $\mathrm{pH}$ range from 3 to 11 . They observed a negligible adsorption at $\mathrm{pH} 3$, indicating the possibility of using this $\mathrm{pH}$ for TME elution and biomass regeneration. Their results clearly indicated that $\mathrm{Zn}^{2+}$ adsorption increased from $\mathrm{pH} 3$ to $\mathrm{pH} 7$ but decreased from $\mathrm{pH} 7$ to $\mathrm{pH} 11$. This increase in $\mathrm{Zn}^{2+}$ removal with increasing $\mathrm{pH}$ up to 7 was also demonstrated by Matos et al. [16] using fungal biomass.

Kumar et al. [14] worked on the adsorption of $\mathrm{Ni}^{2+}$ in the aqueous phase by the bark of MO. Under very acidic conditions ( $\mathrm{pH} 2$ ), the amount of $\mathrm{Ni}^{2+}$ removed was very low (20\%), whereas adsorption was high (35\% to $97 \%$ ) from $\mathrm{pH}$ 3 to 6 and then decreased (97\% to 78\%) when $\mathrm{pH}$ increased from 6 to 8 .

Kalavathy and Miranda [2] worked at different $\mathrm{pH}$ values ranging from 2 to 10 for the adsorption of $\mathrm{Cu}^{2+}, \mathrm{Ni}^{2+}$ and $\mathrm{Zn}^{2+}$ in the aqueous phase by activated carbon from $\mathrm{MO}$ wood. They observed a very low adsorption in the $\mathrm{pH}$ range from 2 to $4(0.2 \%$ to $0.8 \%)$. By increasing the $\mathrm{pH}$ above 6 , the adsorption capacity increased rapidly from $1 \%$ to $1.5 \%$. An optimal $\mathrm{pH}$ of 6 was chosen because metal hydroxide precipitation was observed at $\mathrm{pH}$ above 6 . These data were in agreement with the results obtained by Kalavathy et al. [17].

All these authors having studied the effect of the $\mathrm{pH}$ of the metal solution, made a general observation that the $\mathrm{pH}$ is one of the most important parameters for any adsorption process.

The relationship between $\mathrm{pH}$ and TME removal could be related to the functional groups of the adsorbent used as well as to the nature of the mineral species in solution. Due to their ability to interact with metal ions, these functional groups are likely to increase the adsorption of metal ions [17]. From pH 2.5 to 5 , a high number of hydrogen and hydronium ions compete with metal ions for the metal binding sites on the adsorbent, resulting in poor adsorption of the latter. At $\mathrm{pH}$ values between 5 and 7 , there is little competition due to a lower number of hydrogen ions [18].

\subsection{Effect of Moringa oleifera Particle Size}

The effect of Moringa oleifera particle size has been discussed by several authors (Table 1).

Farrokhzadeh et al. [11] worked with $\mathrm{MO}$ seed powder particles that were prepared in three categories A, B and C $(\mathrm{A}<0.125 \mathrm{~mm} ; 0.125 \mathrm{~mm}<\mathrm{B}<0.420$ $\mathrm{mm}$ and $0.420 \mathrm{~mm}<\mathrm{C}<1.180 \mathrm{~mm}$ ). For these authors, the larger the particle size is, the greater the efficiency of metal removal is. However, some studies reported very small particles of adsorbent [3] [8].

Araujo et al. [10] worked with $\mathrm{MO}$ seed powder particles ranging in size from $0.075 \mathrm{~mm}$ to $0.500 \mathrm{~mm}$, which is smaller than those used by Farrokhzadeh et al. [11]. However, particles with a size close to $0.500 \mathrm{~mm}$ gave better metal removal $\left(\mathrm{Ag}^{+}, 2.31 \%\right)$.

Bhatti et al. [3] worked with $\mathrm{MO}$ particles whose size varied from $0.250 \mathrm{~mm}$ to $0.500 \mathrm{~mm}$. According to these authors, the efficiency of the removal of $\mathrm{Zn}^{2+}$ de- 
creased with increasing particle size (from $0.250 \mathrm{~mm}$ to $0.500 \mathrm{~mm}$ ). Total surface area provides more adsorption sites for the metal ions.

Sharma et al. [8] worked on three different particle sizes of MO seed powders $(0.105 \mathrm{~mm}, 0.210 \mathrm{~mm}$ and $0.420 \mathrm{~mm})$. The removal efficiency of $\mathrm{Cd}^{2+}$ was $85.10 \%$, $70.04 \%$ and $52.20 \%$ for particle sizes of $0.105 \mathrm{~mm}, 0.210 \mathrm{~mm}$ and $0.420 \mathrm{~mm}$ respectively.

Kalavathy and Miranda [2] used $0.074 \mathrm{~mm}$ particles. They obtained an average removal efficiency of $58.7 \%$ for $\mathrm{Zn}^{2+}, \mathrm{Cu}^{2+}$ and $\mathrm{Ni}^{2+}$.

The effect of MO particle size has been a much debated parameter in all previous works. For some authors, the larger the particle size is, the higher the metal removal efficiency is [11] [13] while other authors have reported the opposite effect [3] [8].

\subsection{Effect of Adsorbent Dose}

Table 2 shows the results in relation to the effect of adsorbent dose discussed by

Table 1. Effect of adsorbent particle size.

\begin{tabular}{|c|c|c|c|c|}
\hline TMEs & $\begin{array}{c}\text { Analysis } \\
\text { technique }\end{array}$ & Particle size & $\begin{array}{c}\text { Optimal } \\
\text { particle size }\end{array}$ & References \\
\hline $\begin{array}{l}\mathrm{Mn}^{2+} \mathrm{Ni}^{2+}, \mathrm{Cr}^{3+}, \\
\mathrm{Cu}^{2+}, \mathrm{Fe}^{2+}, \mathrm{Zn}^{2+}\end{array}$ & Sieving & $\begin{array}{c}\text { Three categories: } \\
\mathrm{A}<0.125 \mathrm{~mm} \\
0.125<\mathrm{B}<0.420 \mathrm{~mm} \\
0.420<\mathrm{C}<1.180 \mathrm{~mm}\end{array}$ & $\begin{array}{c}\mathrm{A}\left(\mathrm{Ni}^{2+}, \mathrm{Cr}^{3+},\right. \\
\left.\mathrm{Cu}^{2+}, \mathrm{Fe}^{2+}\right) \\
\mathrm{B}\left(\mathrm{Mn}^{2+}\right) \\
\mathrm{C}\left(\mathrm{Zn}^{2+}\right)\end{array}$ & Farrokhzadeh et al. [11] \\
\hline $\mathrm{Ag}^{+}$ & Sieving & $0.500,0.180,0.075 \mathrm{~mm}$ & $0.500 \mathrm{~mm}$ & Araujo et al. [13] \\
\hline $\mathrm{Zn}^{2+}$ & Sieving & $\begin{array}{c}\text { Three categories: } \\
<0.255 \mathrm{~mm} \\
0.255-0.355 \mathrm{~mm} \\
0.355-0.500 \mathrm{~mm}\end{array}$ & $<0.255 \mathrm{~mm}$ & Bhatti et al. [3] \\
\hline $\mathrm{Cd}^{2+}$ & Sieving & $0.105,0.210,0.420 \mathrm{~mm}$ & $0.105 \mathrm{~mm}$ & Sharma et al. [8] \\
\hline $\mathrm{Cu}^{2+}, \mathrm{Ni}^{2+}, \mathrm{Zn}^{2+}$ & Sieving & $1 \mathrm{~mm}$ & $0.074 \mathrm{~mm}$ & $\begin{array}{c}\text { Kalavathy and Miranda } \\
\text { [2] }\end{array}$ \\
\hline
\end{tabular}

Table 2. Effect of adsorbent dose.

\begin{tabular}{|c|c|c|c|c|}
\hline TMEs & Analysis technique & $\begin{array}{l}\text { Adsorbent dose } \\
\qquad\left(\mathrm{g} \cdot \mathrm{L}^{-1}\right)\end{array}$ & $\begin{array}{l}\text { Optimal dose used } \\
\qquad\left(\mathrm{g} \cdot \mathrm{L}^{-1}\right)\end{array}$ & References \\
\hline $\begin{array}{l}\mathrm{Mn}^{2+}, \mathrm{Ni}^{2+}, \mathrm{Cr}^{3+} \\
\mathrm{Cu}^{2+}, \mathrm{Fe}^{2+}, \mathrm{Zn}^{2+}\end{array}$ & Dilution of standard stock solution and AAS & $5,10,30$ & $\begin{array}{l}5\left(\mathrm{Mn}^{2+} \text { et } \mathrm{Cr}^{3+}\right) \\
10\left(\mathrm{Ni}^{2+} \text { et } \mathrm{Fe}^{2+}\right) \\
30\left(\mathrm{Cu}^{2+} \text { et } \mathrm{Zn}^{2+}\right)\end{array}$ & $\begin{array}{l}\text { Farrokhzadeh et al. } \\
\qquad[1]\end{array}$ \\
\hline $\mathrm{Cd}^{2+}$ & Dilution of standard and Gamma Spectrometry & $2,4,6$ & 4 & Sharma et al. [8] \\
\hline $\mathrm{Ag}^{+}$ & Dilution of standard and AAS & $0.1,0.2,0.3,0.4,1,2,3,4 \mathrm{~g}$ & 2 & Araujo et al. [13] \\
\hline $\mathrm{Zn}^{2+}$ & Dilution of standard stock solution and AAS & $0.5,1,2,3$ & 0.5 & Bhatti et al. [3] \\
\hline $\mathrm{Ni}^{2+}$ & Dilution of standard stock solution and AAS & $\begin{array}{c}0.1,0.2,0.3,0.4,0.5,0.6 \\
0.7,0.8 \mathrm{~g} / \mathrm{L}\end{array}$ & 0.4 & Kumar et al. [19] \\
\hline $\mathrm{Cu}^{2+}, \mathrm{Ni}^{2+}, \mathrm{Zn}^{2+}$ & $\begin{array}{c}\text { Dilution of stock solution of } \mathrm{CuSO}_{4} \cdot 5 \mathrm{H}_{2} \mathrm{O}, \mathrm{NiSO}_{4} \cdot 7 \mathrm{H}_{2} \mathrm{O} \\
\text { and } \mathrm{ZnSO}_{4} \cdot 7 \mathrm{H}_{2} \mathrm{O} \text { and UV Spectrophotometry }\end{array}$ & $0.5,1,1.5,2,3,5,7$ & 0.5 & $\begin{array}{l}\text { Kalavathy and } \\
\text { Miranda [2] }\end{array}$ \\
\hline
\end{tabular}

AAS: Atomic Absorption Spectrometry. 
the authors.

Farrokhzadeh et al. [11] observed a positive relation between the removal efficiency of TMEs and the adsorbent concentration. In the case of $\mathrm{Cu}^{2+}$, the removal efficiency decreased ( $70 \%$ to $9 \%$ ) when the MO dose was increased from $5-10$ $\mathrm{g} / \mathrm{L}$ and then increased (9\% to 70\%) when the dose was increased from $10-20$ $\mathrm{g} \cdot \mathrm{L}^{-1}$. Also, they noted a lower removal of $\mathrm{Cr}^{3+}$ and $\mathrm{Mn}^{2+}$ (70\% to $\left.22 \%\right)$ than that of $\mathrm{Zn}^{2+}, \mathrm{Cu}^{2+}$ and $\mathrm{Fe}^{2+}$ (70\% to $40 \%$ ).

This effect was also reported by Bhatti et al. [3] and Sharma et al. [8] in their respective work on the removal of $\mathrm{Zn}^{2+}$ and $\mathrm{Cd}^{2+}$.

Araujo et al. [13] worked with adsorbent concentrations ranging from 0.1 - 4 $\mathrm{g} \cdot \mathrm{L}^{-1}$ and the maximum removal efficiency $(2.31 \%)$ was obtained with a mass of $2 \mathrm{~g}$.

Bhatti et al. [3] worked with an adsorbent concentration of $0.5 \mathrm{~g} \cdot \mathrm{L}^{-1}$ while Sharma et al. [8] used 2 - $6 \mathrm{~g} / \mathrm{L}$.

Kumar et al. [19] used $0.1-0.8 \mathrm{~g} \cdot \mathrm{L}^{-1}$ and observed a maximum adsorption of $92 \%$ with $0.4 \mathrm{~g} \cdot \mathrm{L}^{-1}$.

Kalavathy and Miranda [2] used concentrations from $0.5-7 \mathrm{~g} \cdot \mathrm{L}^{-1}$. The dose of $0.5 \mathrm{~g} \cdot \mathrm{L}^{-1}$ was the optimum dose in their study for removal of copper, nickel and zinc.

\subsection{Effect of Adsorbent-Metal Contact Time}

The results in relation to the effect of adsorbent metal contact time are presented in Table 3.

Bhatti et al. [3] used a time between $10 \mathrm{~min}$ and $640 \mathrm{~min}$. The optimum adsorption time was 50 minutes.

Sharma et al. [8] studied for a time between $10 \mathrm{~min}$ and $60 \mathrm{~min}$. The percentage of adsorption increased gradually from $10 \mathrm{~min}$ to $30 \mathrm{~min}$ to reach the optimum value at $40 \mathrm{~min}$. Once equilibrium was reached, the percentage adsorption did not change with time.

Araujo et al. [13] worked between 5 - $50 \mathrm{~min}$ and equilibrium was reached in $20 \mathrm{~min}$. Kumar et al. [19] worked between 5 - $100 \mathrm{~min}$ and equilibrium was reached in $60 \mathrm{~min}$. Kalavathy and Miranda [2] worked with a time range from 0 - 300

Table 3. Effect of adsorbent/adsorbate contact time.

\begin{tabular}{ccccc}
\hline TMEs & Analysis technique & $\begin{array}{c}\text { Contact time } \\
(\mathrm{min})\end{array}$ & $\begin{array}{c}\text { Equilibrium } \\
\text { time (min) }\end{array}$ & References \\
\hline $\mathrm{Zn}^{2+}$ & AAS & $10-640$ & 50 & Bhatti et al. [3] \\
$\mathrm{Cd}^{2+}, \mathrm{Pb}^{2+}$ & Gamma Spectrometry & $10-60$ & 40 & Sharma et al. [8] \\
$\mathrm{Ag}^{+}$ & - & $5,20,35,50$ & 20 & Araujo et al. [13] \\
$\mathrm{Ni}^{2+}$ & AAS & $5-100$ & 60 & Kumar et al. [19] \\
& UV & $0-250$ & $60\left(\mathrm{Ni}^{2+}\right)$ & Kalavathy and Miranda \\
$\mathrm{Cu}^{2+}, \mathrm{Ni}^{2+}, \mathrm{Zn}^{2+}$ & Spectrophotometry & & $180\left(\mathrm{Zn}^{2+}\right)$ & [2] \\
\hline
\end{tabular}

AAS: Atomic Absorption Spectrometry. 
min with a maximum adsoprtion in 240 min for copper, 60 min for nickel and $180 \mathrm{~min}$ for zinc. There was no significant change in equilibrium concentration after 240, 60 and 180. Contact times and equilibrium times differ from one metal to anothers

\section{Adsorption Isotherm Models for Moringa Powder}

Studying isotherm models of metal adsorption by MO seed powders are mainly based on these three models (Langmuir, Freundlich, Temkin) and the choice of the best adsorption model for each TME is indicated in Table 4.

\subsection{Langmuir Isotherm Model}

The first fundamental theory of gas adsorption on solids was proposed by Langmuir in 1918 and remains one of the most widely used models in the literature for liquid phase adsorption phenomena [21]. This model is based on the following assumptions:

- Adsorption is localized and only results in the formation of a monolayer;

- All sites are equivalent: the surface is uniform;

- There is no interaction between the adsorbed molecules;

- The reaction is reversible (i.e. there is an equilibrium between adsorption and desorption).

Table 4. Adsorption isotherms.

\begin{tabular}{|c|c|c|c|}
\hline TMEs & Isotherm models & Model validity & References \\
\hline $\begin{array}{l}\mathrm{Mn}^{2+}, \mathrm{Ni}^{2+} \\
\mathrm{Cr}^{3+}, \mathrm{Cu}^{2+} \\
\mathrm{Fe}^{2+}, \mathrm{Zn}^{2+}\end{array}$ & $\begin{array}{l}\text { Langmuir: } \mathrm{Zn}^{2+} \\
\text { Freundlich: } \mathrm{Cr}^{3+} \\
\quad \text { Temkin: } \\
\mathrm{Mn}^{2+}, \mathrm{Cu}^{2+}, \mathrm{Fe}^{2+}\end{array}$ & $\begin{array}{l}\text { Maximum adsorption capacity }\left(\mathrm{mg} \cdot \mathrm{g}^{-1}\right) \\
\qquad \mathrm{Zn}^{2+}: 2.09 \\
\mathrm{Cr}^{3+}: 0.72 \\
\text { Heat-related adsorption constant } \\
\left(\mathrm{mg} \cdot \mathrm{L}^{-1}\right) \\
\mathrm{Fe}^{2+}: 2.09 \\
\mathrm{Cu}^{2+}: 24.98 \\
\mathrm{Mn}^{2+}: 17.35\end{array}$ & $\begin{array}{c}\text { Farrokhzadeh et al. } \\
{[11]}\end{array}$ \\
\hline $\mathrm{Zn}^{2+}$ & $\begin{array}{l}\text { Langmuir } \\
\text { Freundlich }\end{array}$ & 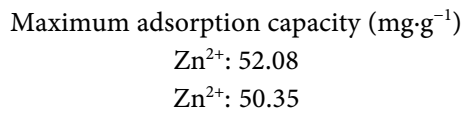 & Bhatti et al. [3] \\
\hline $\mathrm{Cd}^{2+}$ & Freundlich & Freundlich Constant $\mathrm{K}_{\mathrm{F}}\left(\mathrm{L} \cdot \mathrm{g}^{-1}\right): 3.04$ & Sharma et al. [8] \\
\hline $\mathrm{Ni}^{2+}$ & $\begin{array}{l}\text { Langmuir, } \\
\text { Freundlich, } \\
\text { Temkin }\end{array}$ & $\begin{array}{l}\text { Maximum adsorption capacity }\left(\mathrm{mg} \cdot \mathrm{g}^{-1}\right) \\
\qquad \begin{array}{c}\mathrm{Ni}^{2+}: 30.38 \\
- \\
-\end{array}\end{array}$ & Kumar et al. 19] \\
\hline $\begin{array}{c}\mathrm{Cu}^{2+}, \mathrm{Ni}^{2+} \\
\mathrm{Zn}^{2+}\end{array}$ & $\begin{array}{l}\text { Langmuir: } \mathrm{Ni}^{2+} \\
\text { Freundlich: } \mathrm{Zn}^{2+} \\
\text { Temkin: } \mathrm{Cu}^{2+}\end{array}$ & $\begin{array}{l}\text { Maximum adsorption capacity }\left(\mathrm{mg} \cdot \mathrm{g}^{-1}\right) \\
\qquad \begin{array}{l}\mathrm{Ni}^{2+}: 19.08 \\
\mathrm{Zn}^{2+}: 17.67 \\
\mathrm{Cu}^{2+}: 11.53\end{array}\end{array}$ & $\begin{array}{l}\text { Kalavathy and } \\
\text { Miranda [2] }\end{array}$ \\
\hline $\mathrm{Cd}^{2+}, \mathrm{Pb}^{2+}$ & $\begin{array}{l}\text { Langmuir: } \mathrm{Cd}^{2+} \\
\text { Freundlich: } \mathrm{Pb}^{2+}\end{array}$ & $\begin{array}{c}\text { Maximum adsorption capacity }\left(\mathrm{mg} \cdot \mathrm{g}^{-1}\right) \\
\mathrm{Cd}^{2+}: 38.63 / \mathrm{Pb}^{2+}: 24.50 \\
\text { Freundlich Constant } K_{F}\left(\mathrm{~L} \cdot \mathrm{g}^{-1}\right) \\
\mathrm{Cd}^{2+}: 0.36 / \mathrm{Pb}^{2+}: 14.22\end{array}$ & Sahabi et al. [20] \\
\hline
\end{tabular}


The Langmuir isotherm is represented mathematically by the equation:

$$
q_{e}=q_{m}\left[\left(K_{L} C_{e}\right) /\left(1+K_{L} C_{e}\right)\right]
$$

$q_{e}\left(\mathrm{mg} \cdot \mathrm{g}^{-1}\right)$ : the quantity of adsorbed species per gram of solid at equilibrium;

$q_{m}\left(\mathrm{mg} \cdot \mathrm{g}^{-1}\right)$ : the quantity of adsorbed species per gram of solid necessary to cover the surface of the solid with a monolayer; $C_{e}\left(\mathrm{mg} \cdot \mathrm{L}^{-1}\right)$ : the residual concentration of liquid at equilibrium; $K_{L}\left(\mathrm{~L} \cdot \mathrm{mg}^{-1}\right)$ : the Langmuir thermodynamic constant linked to the adsorbate-adsorbent system (specific adsorption constant of the adsorbate on the adsorbent).

The characteristics of the Langmuir isotherm can be expressed by a dimensionless term, called the equilibrium parameter $R_{L}$ [22], which is widely used in the field of chemical engineering for the dimensioning of industrial adsorbers and whose usefulness is the knowledge of the type of equilibrium (favourable or unfavourable for adsorption). This parameter is defined by the relation:

$$
R_{L}=1 /\left(1+K_{L} C_{0}\right)
$$

$C_{0}$ : Initial concentration $\left(\mathrm{mg} \cdot \mathrm{L}^{-1}\right) ; K_{L}$ : Langmuir constant $\left(\mathrm{L} \cdot \mathrm{mg}^{-1}\right)$.

The equilibrium is said to be:

- Favourable if $R_{L}<1$;

- Unfavourable if $R_{L}>1$;

- Linear if $R_{L}=1$;

- Irreversible if $R_{L}=0$.

Table 5 summarises the results of the equilibrium data for the adsorption of TMEs by MO seed powders that were described by the Langmuir isotherm model.

\subsection{Freundlich Isotherm Model}

In 1926, Freundlich proposed another model to describe adsorption in gaseous or liquid media [24]. This model is based on the distribution of pollutants between the surface of the adsorbent and the liquid phase at equilibrium and takes into account the heterogeneity of the adsorbent surface. It is based on the following assumptions:

- Existence of adsorbed multilayers;

- Absence of saturation phenomenon;

- Possibility of interaction between the adsorbed species;

- Heterogeneous distribution of adsorption energies.

The Freundlich isotherm model is represented by a two parameter equation $\left(K_{F}\right.$ and $n$ ) given by the following relation.

$$
q_{e}=K_{F} C_{e}^{1 / n}
$$

where $K_{F}\left(\mathrm{mg} \cdot \mathrm{g}^{-1}\right)$ and $1 / n$ represent the Freundlich constant and the adsorption intensity respectively.

$K_{F}$ and $1 / n$ are the Freundlich constants to be assessed for each solution and for each temperature. The feasibility of the adsorption process depends on the value of $1 / n$ : 
Table 5. Adsorption of TMEs by MO seed powders described by the Langmuir isotherm model.

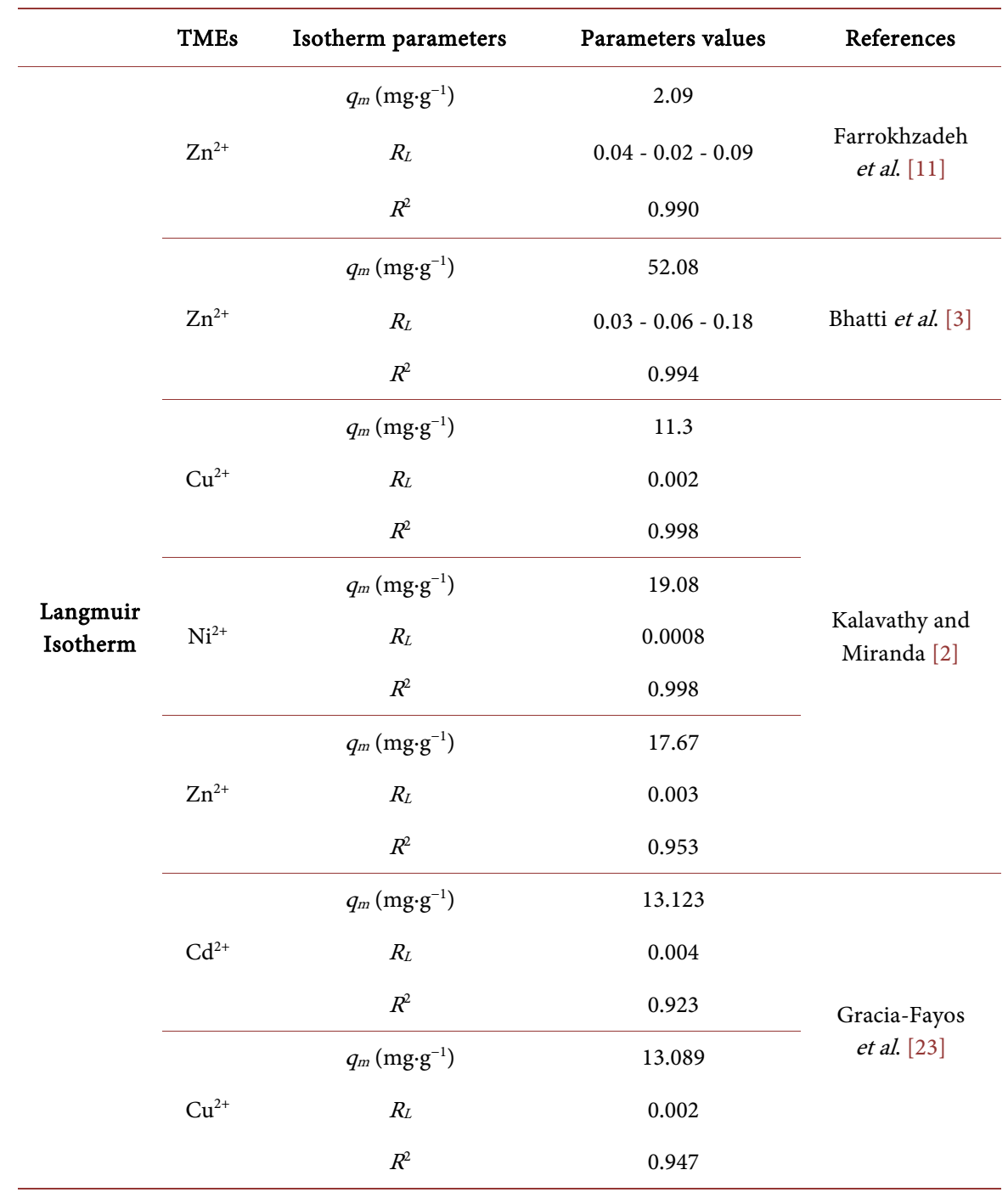

- $1 / n<1$ implies a favourable adsorption;

- $1 / n>1$ implies an unfavourable adsorption.

Table 6 summarises the results of the equilibrium data for adsorption of TMEs by OM seed powder that were described by the Freundlich isotherm model.

\subsection{Temkin Isotherm Model}

The Temkin isotherm is used in several adsorption processes. This model considers a non-uniform surface, a preferential occupation of the most adsorptive sites and an interaction between the adsorbate molecules and the adsorbent material. Temkin's model is based on the assumption that, during gas phase adsorption, the heat of adsorption due to interactions with the adsorbate decreases linearly with the recovery rate $\theta$. Dipu et al. [25] propose to use this model in the liquid phase by plotting $q_{e}$ or $\theta$ as a function of $\ln \left(C_{e}\right)$ given by the following relationship. 
Table 6. Adsorption of TMEs by MO seed powders described by the Freundlich isotherm model.

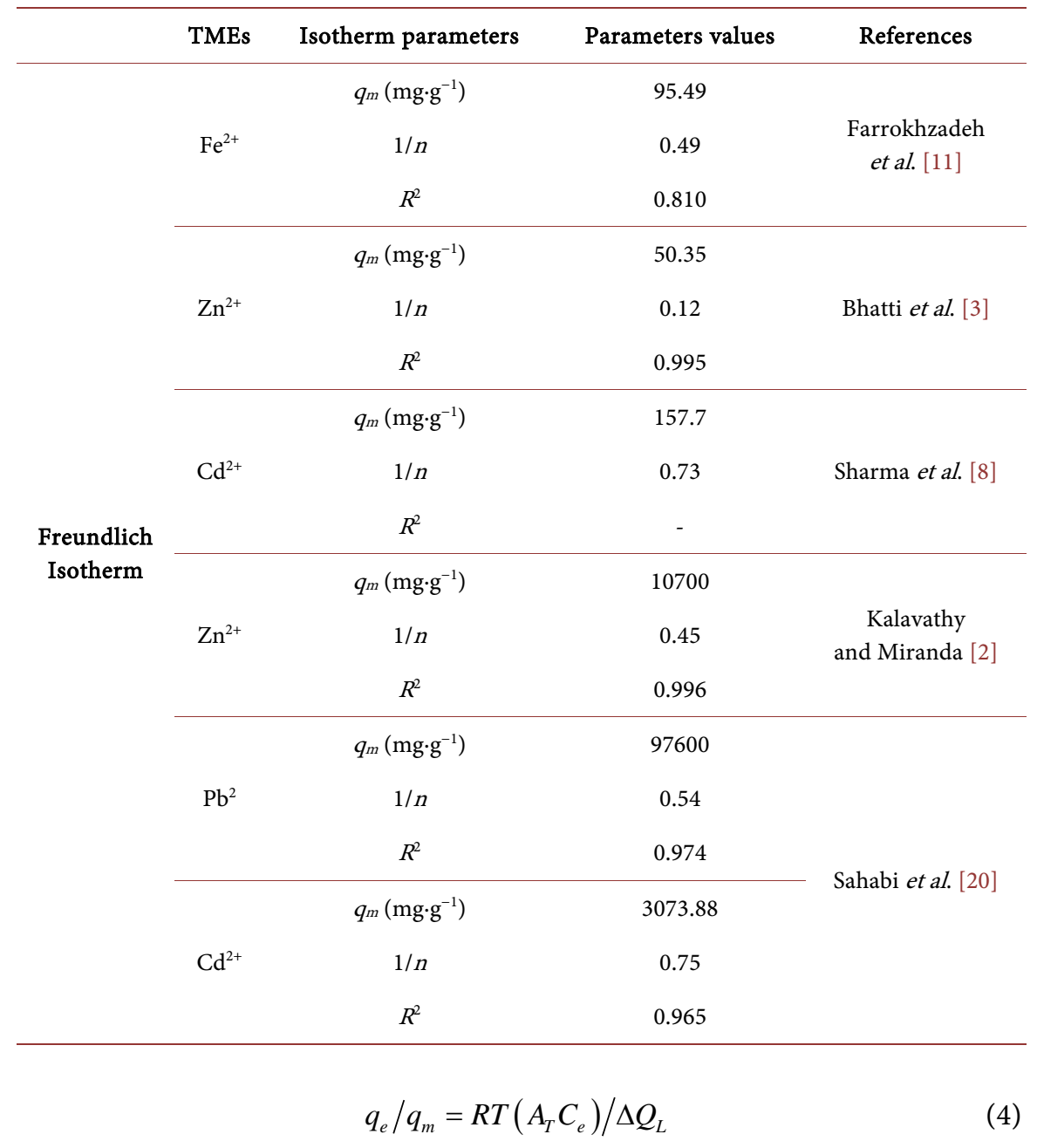

The linear form of the Temkin isotherm is given by the following équation:

$$
q_{e}=B \ln A_{T}+B \ln C_{e}
$$

where $B=R T / b_{T}\left(\mathrm{~J} \cdot \mathrm{mol}^{-1}\right)$ is related to the heat of adsorption; $R$ the perfect gas constant $\left(8.314 \mathrm{~J} \cdot \mathrm{K}^{-1} \cdot \mathrm{mol}^{-1}\right) ; T(\mathrm{~K})$ the absolute temperature; $b_{T}$ the Temkin isotherm constant; $\Delta Q$ the change in adsorption energy $\left(\mathrm{J} \cdot \mathrm{mol}^{-1}\right)$ and $A_{T}\left(\mathrm{~L} \cdot \mathrm{g}^{-1}\right)$ the equilibrium binding constant corresponding to the maximum binding energy.

In Table 7, the results of the equilibrium adsorption data of TMEs by MO were described by the Temkin isotherm model.

Farrokhzadeh et al. [11] showed in their study on the removal of TMEs $\left(\mathrm{Mn}^{2+}\right.$, $\mathrm{Ni}^{2+}, \mathrm{Cr}^{3+}, \mathrm{Cu}^{2+}, \mathrm{Fe}^{2+}$ and $\mathrm{Zn}^{2+}$ ) by deshelled M. oleifera seed powders in aqueous solution that the appropriate isotherm model for $\mathrm{Zn}^{2+}$ adsorption was the Langmuir model. The graphical representation of this model $\left[1 / q_{e}=f\left(1 / C_{e}\right)\right]$ gave a straight line with a coefficient of determination $R^{2}=0.99, R_{L}$ values between 0 and $1(0.045 ; 0.023 ; 0.087)$ with a maximum adsorption capacity of $2.09 \mathrm{mg} \cdot \mathrm{g}^{-1}$.

The Langmuir and Freundlich isotherms were appropriate for $\mathrm{Cr}^{3+}$. The Temkin isotherm was the best model for the adsorption of $\mathrm{Fe}^{2+}, \mathrm{Cu}^{2+}$ and $\mathrm{Mn}^{2+}$. In the 
Table 7. Adsorption of TMEs by MO seed powders described by the Temkin isotherm model.

\begin{tabular}{|c|c|c|c|c|}
\hline & TMEs & Isotherm parameters & Parameters values & References \\
\hline \multirow{6}{*}{$\begin{array}{l}\text { Temkin } \\
\text { Isotherm }\end{array}$} & & $A_{T}\left(\mathrm{~J} \cdot \mathrm{mol}^{-1}\right)$ & 36.19 & \multirow{3}{*}{ Farrokhzadeh et al. [11] } \\
\hline & $\mathrm{Cu}^{2+}$ & $B_{T}\left(\mathrm{~L} \cdot \mathrm{g}^{-1}\right)$ & 24.98 & \\
\hline & & $R^{2}$ & 0.980 & \\
\hline & \multirow{3}{*}{$\mathrm{Cu}^{2+}$} & $A_{T}\left(\mathrm{~J} \cdot \mathrm{mol}^{-1}\right)$ & 2.79 & \multirow{3}{*}{ Kalavathy and Miranda } \\
\hline & & $B_{T}\left(\mathrm{~L} \cdot \mathrm{g}^{-1}\right)$ & 1.20 & \\
\hline & & $R^{2}$ & 0.999 & \\
\hline
\end{tabular}

case of $\mathrm{Ni}^{2+}$, the adsorption reaction could not be associated with the isotherms studied.

Bhatti et al. [3] studied Langmuir and Freundlich isotherms for the metal ion $\mathrm{Zn}^{2+}$. These authors show that the coefficients of determination $\left(R^{2}\right)$ of the two models are 0.994 and 0.995 respectively. This indicates that both models correctly describe the experimental data of these $\mathrm{Zn}^{2+}$ metal adsorption experiments.

Sharma et al. [8] analysed the $\mathrm{Cd}^{2+}$ adsorption data using the Freundlich isotherm which accurately described the adsorption behaviour of this ion.

Kumar et al. [19] applied the experimental data to the Langmuir, Freundlich, and Temkin isotherm models. In addition to determining the coefficient of determination $\left(R^{2}\right)$, the chi-square test $\left(\chi^{2}\right)$ was performed to determine the best isotherm model. These authors observed from the values of the coefficient of determination $R^{2}$ (0.997) and the chi-square test $\chi^{2}(1.413)$ that the Langmuir model best described the $\mathrm{Ni}^{2+}$ adsorption phenomenon. This was followed by the models of Temkin (0.967), Freundlich (0.945).

The previous four models were also studied by Kalavathy and Miranda [2] to describe the equilibrium data for $\mathrm{Cu}^{2+}, \mathrm{Ni}^{2+}$ and $\mathrm{Zn}^{2+}$ adsorption. These authors observed $R^{2}$ values of $0.990,0.970$ and 0.980 respectively for the Langmuir, Freundlich and Temkin models for $\mathrm{Cu}^{2+}$ adsorption. However, the $R^{2}$ values were higher in the Langmuir model for $\mathrm{Ni}^{2+}(0.997)$ and in the Freundlich model for $\mathrm{Zn}^{2+}$ (0.995). The Temkin isotherm had a higher $R^{2}$ for all metal ions (0.98).

The analysis of the monolayer adsorption capacity with temperature by these authors indicates that adsorption is an endothermic process for $\mathrm{Cu}^{2+}$ and exothermic for $\mathrm{Ni}^{2+}$ and $\mathrm{Zn}^{2+}$. The values of the Freundlich isotherm constant ( $\mathrm{n}$ ) are between 2.17 and 2.92, which indicates a favourable adsorption process. Kalavathy and Miranda observed that the monolayer adsorption capacity (Langmuir isotherm) is maximum in the case of $\mathrm{Ni}^{2+}\left(19.08 \mathrm{mg} \cdot \mathrm{g}^{-1}\right)$, followed by $\mathrm{Zn}^{2+}$ $\left(17.67 \mathrm{mg} \cdot \mathrm{g}^{-1}\right)$ and $\mathrm{Cu}^{2+}\left(11.53 \mathrm{mg} \cdot \mathrm{g}^{-1}\right)$.

Sahabi et al. [20] observed, based on the $\left(R^{2}\right)$ values, that the Freundlich model best described the adsorption process of $\mathrm{Pb}^{2+}$ and $\mathrm{Cd}^{2+}$ ions. The fit of the $\mathrm{Cd}^{2+}$ equilibrium data to the Freundlich isotherm model is in agreement with the study of. Sharma et al. [8], who had already revealed that the adsorption of cadmium by MO seed powder was consistent with this model. On the other hand, 
the fitting of $\mathrm{Pb}^{2+}$ equilibrium data to the Freundlich and Langmuir models did not agree with the findings of Adelaja et al. [26], who revealed that $\mathrm{Pb}^{2+}$ adsorption by MO seed powder was not consistent with these two isotherm models.

The authors generally noted that the values of $\left(R^{2}\right)$ and the parameters related to each isotherm $\left(R_{L}, 1 / n\right.$ and $\left.B_{T}\right)$ are important factors in the interpretation of the experimental data of the TMEs adsorption process. The choice of the adsorption isotherm depends on the type of surface of the adsorbent (monolayer, heterogeneous surface...), but also on the temperature (endothermic or exothermic process). The Langmuir model assumes that adsorption is limited to a monolayer, whereas the Freundlich model is an empirical analysis describing the adsorption of solutes from a liquid on the surface of a solid, thus assuming a heterogeneous adsorption surface. The Temkin isotherm assumes that the heat of adsorption of all molecules in the layer decreases linearly with coverage due to adsorbent-adsorbate interactions.

\section{Conclusions}

In this article, we have presented different factors responsible for TMEs retention by $\mathrm{MO}$ as well as different models of adsorption isotherms that best approximate the retention capacities.

The optimal conditions for the removal of TMEs differ from one metal to another. Overall, it can be said that the different parameters (initial metal concentration, $\mathrm{pH}$, particle size, adsorbent dose, contact time and adsorption isotherms) impacted the removal capacity of the TMEs present in the aqueous solutions.

However, an optimisation of these parameters must be performed, which is essential for a better performance of the adsorption process.

\section{Conflicts of Interest}

The authors declare no conflicts of interest regarding the publication of this paper.

\section{References}

[1] Duffus, I.H. (2002) Heavy Metals-A Meanigles Term? Pure and Applied Chemistry, 74, 793-807. https://doi.org/10.1351/pac200274050793

[2] Kalavathy, H.M. and Miranda, L.R. (2010) Moringa oleifera-A Solid Phase Extractant for the Removal of Copper, Nickel and Zinc from Aqueous Solutions. Chemical Engineering Journal, 158, 188-199. https://doi.org/10.1016/j.cej.2009.12.039

[3] Bhatti, H.N., Mumtaz, B., Hanif, M.A. and Nadeem, R. (2007) Removal of Zn(II) Ions from Aqueous Solution Using Moringa oleifera Lam. (Horseradish Tree) Biomass. Process Biochemistry, 42, 547-553. https://doi.org/10.1016/j.procbio.2006.10.009

[4] Ahluwalia, S.S. and Goyal, D. (2007) Microbial and Plant Derived Biomass for Removal of Heavy Metals from Wastewater. Bioresource Technology, 98, 2243-2257. https://doi.org/10.1016/j.biortech.2005.12.006

[5] Ghebremichael, K.A., Gunaratna, K.R., Henriksson, H., Brumer, H. and Dalham- 
mar, G. (2005) A Simple Purification and Activity Assay of the Coagulant Protein from Moringa oleifera Seed. Water Research, 39, 2338-2344. https://doi.org/10.1016/j.watres.2005.04.012

[6] Athéba, G.P., Allou, N.B., Dongui, B.K., Kra, D.O., Gbassi, K.G. and Trokourey, A. (2015) Adsorption of Butylparaben on Activated Carbon Based on Coconut Husks from Ivory Coast. International Journal of Innovation and Scientific Research, 13, 530-541.

[7] Tanauh, O.M. (2016) Évaluation des usages du moringa, du soja et de la spiruline à Abidjan (Evaluation of Moringa, Soybean and Spirulina Uses in Abidjan). Thesis in Pharmacy, FHB University, Abidjan.

[8] Sharma, P., Kumari, P., Srivastava, M.M. and Srivastava, S. (2006) Removal of Cadmium from Aqueous System by Shelled Moringa oleifera Lam. Seed Powder. Bioresource Technology, 97, 299-305. https://doi.org/10.1016/j.biortech.2005.02.034

[9] Pollard, S.J.T., Thompson, F.E. and Mcconnachie, G.L. (1994) Microporous Carbons from Moringa oleifera Husk for Water Purification in Less Developed Countries. Water Research, 29, 337-347. https://doi.org/10.1016/0043-1354(94)E0103-D

[10] Yehe, M.D. and Gbassi, G.K. (2019) Étude physico-chimique d'un coagulant naturel: la poudre de graines de Moringa oleifera. Revue ivoirienne des sciences et technologie, 33, 287-299.

[11] Farrokhzadeh, H., Taheri, E., Ebrahimi, A., Fatehizadeh, A., Dastjerdi, M.V. and Bina, B. (2013) Effectiveness of Moringa oleifera Powder in Removal of Heavy Metals from Aqueous Solutions. Fresenius Environmental Bulletin, 22, 1516-1523.

[12] Ajmal, M., Rao, R., A.K., Anwar, S., Ahmad, J. and Ahmad, R. (2003) Adsorption Studies on Rice Husk: Removal and Recovery of Cd(II) from Wastewater. Bioresource Technology, 86, 147-149. https://doi.org/10.1016/S0960-8524(02)00159-1

[13] Araujo, C., Alves, V.N., Almeida, I., Assunção, R., Tarley, C., Coelho, N., Rezende, H. and Segatelli, M.G. (2010) Characterization and Use of Moringa oleifera seeds as Biosorbent for Removing Metal Ions from Aqueous Effluents. Water Science \& Technology, 62, 2198-2203. https://doi.org/10.2166/wst.2010.419

[14] Alves, V.N., Mosquettaa, R., Coelho, N., Bianchin, J.N., Pietro Roux, K.C., Martendal, E. and Carasek, E. (2010) Determination of Cadmium in Alcohol Fuel Using Moringa oleifera Seeds as a Biosorbent in an On-Line System Coupled to FAAS. Talanta, 80, 1133-1138. https://doi.org/10.1016/j.talanta.2009.08.040

[15] Cleide, S.T., Araújo, C., Martendal, E., et al. (2010) Moringa oleifera Lam. Seeds as a Natural Solid Adsorbent for Removal of AgI in Aqueous Solutions. Journal of the Brazilian Chemical Society, 21, 1727-1732. https://doi.org/10.1590/S0103-50532010000900019

[16] Matos, G.D. and Arruda, M.A.Z. (2003) Vermicompost as Natural Adsorbent for Removing Metal Ions from Laboratory Effluents. Process Biochemistry, 39, 81-88. https://doi.org/10.1016/S0032-9592(02)00315-1

[17] Kalavathy, M.H., Karthikeyan, T., Rajgopal, S. and Miranda, L.R. (2005) Kinetic Andisotherm Studies of $\mathrm{Cu}(\mathrm{II})$ Adsorption onto $\mathrm{H}_{3} \mathrm{PO}_{4}$ Activated Rubber Wood Sawdust. Journal of Colloid and Interface Science, 292, 354-362. https://doi.org/10.1016/j.jcis.2005.05.087

[18] Brostlap, A.C. and Schuurmans, J. (1988) Kinetics of L-Valine Uptake in Tobacco Leaf Disc. Comparison of Wild-Type, the Digenic Mutant Valr-2, and Its Monogenic Derivatives. Planta, 176, 42-50. https://doi.org/10.1007/BF00392478

[19] Kumar, D.H.R., Ramana, D.K.V., Seshaiah, K. and Reddy A.V.R. (2011) Biosorption of $\mathrm{Ni}(\mathrm{II})$ from Aqueous Phase by Moringa oleifera Bark, a Low Cost Biosorbent. 
Desalination, 268, 150-157. https://doi.org/10.1016/j.desal.2010.10.011

[20] Saadabi, A.M. and Abu, Z. (2011) An in Vitro Antimicrobial Activity of Moringa oleifera L. Seed Extracts against Different Groups of Microorganisms. Australian Journal of Basic and Applied Sciences, 5, 129-134.

[21] Hameed, B.H., Salman, J.M. and Ahmad, A.L. (2009) Adsorption Isotherm and Kinetic Modeling of 2,4-D Pesticide on Activated Carbon Derived from Date Stones. Journal of Hazardous Materials, 163, 121-126. https://doi.org/10.1016/j.jhazmat.2008.06.069

[22] Fayoud, N., Alami, Y.S., Tahiri, S. et abizane, A. (2015) Etude cinétique et thermodynamique de l'adsorption de bleu de méthylène sur les cendres de bois (Kinetic and Thermodynamic Study of the Adsorption of Methylene Blue on Wood Ashes). Journal of Materials and Environmental Science, 6, 3295-3306.

[23] García-Fayos, B., Arnal, J.M., Verdu, G. and Sauri, A. (2010) Study of Moringa oleifera Oil Extraction and Its Influence in Primary Coagulant Activity for Drinking Water Treatment. International Conference on Food Innovation, Vol. 5, Valencia, 25-29 October 2010, 22-29.

[24] Gupa, S. and Bhattacharyya, K.G. (2006) Adsorption of Ni(II) on Clays. Journal of Colloid and Interface Science, 295, 21-32. https://doi.org/10.1016/j.jcis.2005.07.073

[25] Dipu, B., Shigeo, S. and Shigeru, K. (2008) Surface Modified Carbon Black for As(V) Removal. Journal of Colloid and Surface Science, 319, 53-62. https://doi.org/10.1016/j.jcis.2007.11.019

[26] Adelaja, O.A., Amoo, I.A. and Aderibigbe, A.D. (2011) Biosorption of Lead(II) Ions from Aqueous Solution Using Moringa oleifera Pods. Archives of Applied Science Research, 3, 50-60. 